\title{
Interferon- $\gamma$ inhibits integrin-mediated adhesion to fibronectin and survival signaling in thyroid cells
}

\author{
Marcella Salzano ${ }^{1}$, Eleonora Russo ${ }^{1}$, Loredana Postiglione ${ }^{1}$, Anna Guerra, Vincenzo Marotta ${ }^{2}$, \\ Silvano Esposito and Mario Vitale \\ Department of Medicine and Surgery, University of Salerno, Via Allende, 84081 Baronissi, Salerno, Italy \\ Departments of ${ }^{1}$ Cellular and Molecular Biology and Pathology and ${ }^{2}$ Clinical and Molecular Endocrinology and Oncology, University 'Federico II', 80131 \\ Naples, Italy \\ (Correspondence should be addressed to M Vitale; Email: mavitale@unisa.it)
}

\begin{abstract}
Hashimoto's thyroiditis is the most frequent autoimmune disorder, characterized by the presence of a large lymphocytic infiltration and secretion of inflammatory cytokines in the thyroid. Infiltrating lymphocytes and cytokines play a pivotal role in the progression of HT, characterized by the progressive destruction of the normal follicular architecture of the gland and death of follicular cells, ending with loss of thyroid function. Integrins are plasma membrane receptors for the cell-extra-cellular matrix components, with both structural and signaling functions. Integrin-mediated fibronectin (FN) binding is necessary for the correct function and survival of thyroid follicular cells. The purpose of this study was to determine the effect of interferon- $\gamma($ IFN- $\gamma$ ) stimulation on integrin expression and signaling in the thyroid cell. Cytotoxicity,
\end{abstract}

integrin expression, cell adhesion to FN, and FN-stimulated ERK and AKT phosphorylation were determined in a normal human thyroid cell line treated with IFN- $\gamma$. IFN- $\gamma$ induced apoptosis and reduced the expression of the integrin $\alpha_{v} \beta 3$. Integrin-mediated cell adhesion to FN was strongly impaired. Similarly, FN-stimulated ERK and AKT phosphorylation were inhibited. In conclusion, our study in a thyroid cell model demonstrates that IFN- $\gamma$ induces apoptosis and inhibits the expression of the integrin $\alpha_{v} \beta 3$, reducing cell adhesion to $F N$ and the succeeding outside-in signaling. These results suggest that integrins mediate the cytotoxic effect of IFN- $\gamma$ and are involved in the destructive mechanism of autoimmune thyroiditis.

Journal of Endocrinology (2012) 215, 439-444

\section{Introduction}

Chronic lymphocytic thyroiditis, also known as Hashimoto's thyroiditis (HT), is the most common autoimmune disease, with a prevalence of $5-10 \%$ in the general population (Tunbridge et al. 1977, 1981). Auto-antibodies to thyroid antigens and lymphocyte infiltration on histology are the hallmark of HT (Stassi et al. 2000, Caturegli et al. 2007). A transient modest hyperthyroidism and a small goiter can be the first clinical findings of this disease until the gradual loss of thyroid function appears with hypothyroidism. The reduced thyroid function is due to the progressive destruction of the normal follicular architecture of the gland and death of follicular cells. T helper type 1 (Th1) is the main subset of lymphocytes present in HT and has a crucial role in the pathogenesis of the disease by secreting inflammatory cytokines such as interferon- $\gamma$ (IFN- $\gamma$; Salgame et al. 1991, Romagnani 1994, Carter \& Dutton 1996, Pala et al. 2000, Mazziotti et al. 2003, Santaguida et al. 2011). The role of IFN- $\gamma$ in the pathogenesis of thyroid damage in HT is supported by the evidence of intra-thyroidal cytokine secretion and by experimental evidences in cells in culture and in animal models (Liblau et al. 1995, Roura-Mir et al. 1997, 2005, Stassi et al. 2000, 2001).

Integrins are a group of cell-surface heterodimers characterized by a common $\beta 1$ chain non-covalently associated with a distinctive $\alpha$ subunit (Hemler et al. 1987). The members of this family are receptors for the components of the extra-cellular matrix (ECM), involved in cell-ECM interactions. Their level of expression undergoes quantitative and qualitative changes upon differentiation, neoplastic transformation, and hormone stimulation (Dedhar 1989, Heino \& Massague 1989, Plantefaber \& Hynes 1989, Wilkins et al. 1991, Vitale et al. 1994, 1995). The $\alpha \beta$ integrin complex binds ECM by its extracellular domain and interacts with cytoskeletal proteins by its intracellular domain, contributing to the stability of the tissue architecture (Otey et al. 1990). Some integrins are components of a subcellular structure called focal adhesion, where they interplay with regulatory proteins (Luna \& Hitt 1992). Integrin binding to the ECM generates multiple intracellular signals that contribute to the regulation of many cell processes, including differentiation, 
growth, and survival (Mortarini et al. 1992, Pasqualini \& Hemler 1994). The integrin expression profile is cell-typedependent and is modulated by a number of factors, including cell-to-cell contact, extracellular soluble factors, and tumor transformation. Normal thyroid cells have a limited integrin expression repertoire ( $\alpha 3 \beta 1$ and $\alpha \mathrm{v} \beta 3)$ that changes upon cell-to-cell contact and tumor transformation (Vitale et al. 1993, 1994, 1995, Illario et al. 2003). Integrin activation by fibronectin (FN) has important biological effects in the thyroid cell, regulating cytoskeletal organization and stimulating cell proliferation and survival (Vitale et al. 1998, Di Matola et al. 2000). The aim of this study was to investigate whether integrins mediate the cytotoxic effect exerted by IFN- $\gamma$ on thyroid cells. For this purpose, we investigated the effect of IFN- $\gamma$ on cytotoxicity, integrin expression, adhesion to FN, and FN-stimulated signaling in a human thyroid cell model. We found that INF- $\gamma$ reduces the expression of the integrin $\alpha_{\mathrm{v}} \beta 3$ and strongly inhibits the FN-dependent intracellular signalings, modulating cell proliferation and survival.

\section{Materials and Methods}

\section{Cell cultures}

The TAD2 cell line, obtained by Simian virus 40 infection of human fetal thyroid cells, was generously donated by Dr T F Davies (Mount Sinai Hospital, New York, NY, USA) and cultured in a $5 \% \mathrm{CO}_{2}$ atmosphere at $37^{\circ} \mathrm{C}$ in DMEM ( $4.5 \mathrm{~g}$ glucose) and 10\% FCS. The TAD2 cell line has the same integrin expression profile and FN-stimulated signaling of normal human thyroid cells in culture (Vitale et al. 1997, Illario et al. 2003). Medium was changed every 3-4 days. Cells were detached by $0.5 \mathrm{~mm}$ EDTA in calcium- and magnesium-free PBS with $0 \cdot 05 \%$ trypsin. When needed, the cells were serum starved in $0.5 \%$ BSA and DMEM for $12-18 \mathrm{~h}$ before stimulation. To obtain a FN or BSA coating, cell culture plates were filled with the appropriate FN (Collaborative Research, Bedford, MA, USA) or BSA (Sigma) dilution in PBS. After overnight incubation at $4{ }^{\circ} \mathrm{C}$, FN was removed, and the plates were washed with PBS and stored at $4{ }^{\circ} \mathrm{C}$.

\section{Antibodies to integrins and flow cytometric analysis}

All the antibodies specific for single integrin subunits or heterodimers were mouse monoclonals purchased from Santa Cruz Biotechnology, Inc. Fluorescein-conjugated anti-mouse $\operatorname{IgG}$ was purchased from Ortho (Raritan, NJ, USA). Cells harvested from cell cultures by trypsin/PBS were incubated with MABs for $1 \mathrm{~h}$ at $4{ }^{\circ} \mathrm{C}$ in PBS and $0.5 \%$ BSA (BSA/PBS), washed in the same buffer, and incubated again with the second fluorescein-conjugated antibody for $30 \mathrm{~min}$ at $4{ }^{\circ} \mathrm{C}$. Cells were resuspended in BSA/PBS and analyzed by flow cytometry. Single cell suspensions were analyzed by a
FACScan (Becton Dickinson, Mountain View, CA, USA). Forward scatter vs side scatter analysis was performed on a logarithmic scale using a high forward threshold to cut off cellular and collagen debris. Cytofluorimetric estimation of DNA cell content was performed as described (Illario et al. 2003). Floating cells were collected, washed in cold PBS, added to adherent cells, and trypsinized. Cells were washed again in PBS and fixed in 70\% cold ethanol for $30 \mathrm{~min}$. Ethanol was removed by two PBS washes, and cells were incubated in PBS, $50 \mu \mathrm{g} / \mathrm{ml}$ propidium iodide, $10 \mu \mathrm{g} / \mathrm{ml}$ ribonuclease $\mathrm{A}$, and deoxyribonuclease-free overnight at $4{ }^{\circ} \mathrm{C}$. Cells were then analyzed by flow cytometry using a FACScan.

\section{Cell attachment assay}

The assay was performed in 96-well flat-bottomed microtiter plates (Costar, Cambridge, MA, USA). The wells were filled with $100 \mathrm{ml}$ of the appropriate dilution in PBS of FN (Collaborative Research). After overnight incubation at $4{ }^{\circ} \mathrm{C}$, the plates were washed with PBS, filled with $100 \mathrm{ml}$ $1 \%$ heat-denatured BSA, and incubated for $1 \mathrm{~h}$ at room temperature. Then, plates were washed and filled again with $100 \mathrm{ml} /$ well PBS, $0.9 \mathrm{mM} \mathrm{CaCl}$, and $0.5 \mathrm{mM} \mathrm{MgCl}_{2}$ containing $2 \times 10^{4}$ cells. After $30 \mathrm{~min}$ at $37^{\circ} \mathrm{C}$, plates were gently washed three times with PBS, and the attached cells were fixed with $3 \%$ paraformaldehyde for $10 \mathrm{~min}$ followed by $2 \%$ methanol for $10 \mathrm{~min}$ and finally stained with $0 \cdot 5 \%$ crystal violet in $20 \%$ methanol. After $10 \mathrm{~min}$, plates were washed with tap water, the stain was eluted with a solution of $0 \cdot 1 \mathrm{M}$ sodium citrate, $\mathrm{pH} 4 \cdot 2$, in $50 \%$ ethanol, and the absorbance at $540 \mathrm{~nm}$ was measured by a spectrophotometer. Where indicated, the cells were coincubated with $500 \mu \mathrm{g} / \mathrm{ml}$ of integrin/FN-binding inhibitory peptide RGSP (Gly-Arg-Gly-Asp-Ser-Pro) or the ineffective peptide RGE (Gly-Arg-Gly-Glu-Ser-Pro), Telios (San Diego, CA, USA). All experiments were performed in quadruplicate.

\section{Western blot}

The cells were lysed in Laemmli buffer $(125 \mathrm{mM}$ Tris (pH 6.8), 5\% glycerol, 2\% SDS, 1\% 2 $\beta$-mercaptoethanol, and $0 \cdot 006 \%$ bromophenol blue) and resolved by SDS-PAGE. Proteins were then transferred to a nitrocellulose membrane (Immobilon P, Millipore Corp., Bedford, MA, USA). Membranes were blocked by $5 \%$ nonfat dry milk, $1 \%$ ovalbumin, $5 \% \mathrm{FCS}$, and $7 \cdot 5 \%$ glycine, and after three washes, the membranes were incubated for $1 \mathrm{~h}$ at $4{ }^{\circ} \mathrm{C}$ with mouse monoclonal primary antibodies in PBS. After three washes, filters were incubated for $1 \mathrm{~h}$ at $4{ }^{\circ} \mathrm{C}$ with a HRP-conjugated anti-mouse secondary antibody. After a final wash, protein bands were detected by an ECL system (Amersham Pharmacia Biotech). Mouse MABs to ERK and phosphorylated ERK, Akt and phospho-threonine308-Akt, caspase-3, and PARP were from Santa Cruz Biotechnology, Inc. 


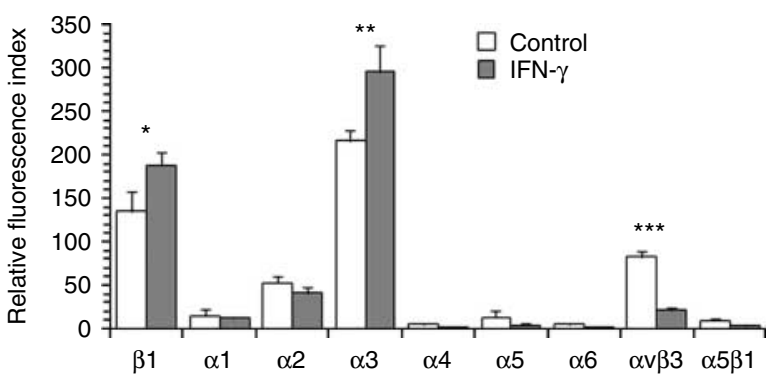

Figure $1 \mathrm{IFN}-\gamma$ modulates integrin expression. TAD2 cells cultured at low confluence were treated for 3 days with IFN $-\gamma(10 \mathrm{ng} / \mathrm{ml})$, harvested by mild trypsinization, and incubated with MABs specific for single integrin subunits $(\beta 1, \alpha 1, \alpha 2, \alpha 3, \alpha 4, \alpha 5$, and $\alpha 6)$ or whole receptors ( $\alpha 5 \beta 1$ and $\alpha v \beta 3$ ) followed by the secondary fluoresceinconjugated antibody. The relative fluorescences were measured by flow cytometry as described in Materials and Methods section. The expression of each integrin etherodimer or single subunit is reported as relative fluorescence index: mean of experimental mean fluorescence/control mean fluorescence of three independent primary cultures. ${ }^{*} P=0 \cdot 048$; ${ }^{* *} P=0 \cdot 039 ;{ }^{* *} P=0 \cdot 0017$ by Student's $t$-test.

\section{Statistical analysis}

Results are presented as the mean \pm s.D. Statistical analysis was performed using the Student's $t$-test or by two-way ANOVA. The level of significance was set at $P<0 \cdot 05$. Statistical analyses were conducted using SPSS 18.0 (IBM Corporation).

\section{Results}

$I N F-\gamma$ modulates the expression of FN receptors of the integrin family in TAD2 cells

All the experiments were performed with TAD2 cells cultured at $75 \%$ confluence. The cells were treated for 3 days with IFN- $\gamma$, then integrin expression was assessed by flow cytometry with specific antibodies for the subunits $\beta 1$, $\alpha 1, \alpha 2, \alpha 3, \alpha 4, \alpha 5, \alpha 6$, or the heterodimers $\alpha v \beta 3$ and $\alpha 5 \beta 1$ (Fig. 1). The expression of the $\alpha 3$ and $\beta 1$ subunits was increased by INF- $\gamma$ treatment. More robust was the effect of INF- $\gamma$ on the $\alpha_{\mathrm{v}} \beta 3$ heterodimer, whose expression was reduced by $76 \cdot 6 \%$.

\section{IFN- $\gamma$ inhibits thyroid cell adhesion to FN}

To investigate whether the adhesion of thyroid cells to FN was changed by IFN- $\gamma$, TAD2 cells were treated with the cytokine for 3 days and a cell attachment assay was performed (Fig. 2). Cell adhesion in the presence of the RGDSP peptide, a specific inhibitor of integrin binding to $\mathrm{FN}$, was reduced by $84.7 \%$, demonstrating the major role of integrin receptors in the adhesion to immobilized FN. IFN- $\gamma$ treated cells showed a remarkable reduction of attachment to FN. The reduction of integrin-dependent attachment (CTRL + RGE$\mathrm{CTRL}+\mathrm{GRDSP} / \mathrm{IFN}-\gamma+\mathrm{RGE}-\mathrm{CTRL}+\mathrm{GRDSP})$ in
10 and $50 \mu \mathrm{g} / \mathrm{ml} \mathrm{FN}$ adhesion assays was 71 and $65 \%$ respectively. Two-way ANOVA assessment of effects of IFN- $\gamma$ indicated a significant difference between IFN $-\gamma+\mathrm{RGE}$ and CTRL + RGE $(F-$ ratio $=5 \cdot 38, \quad P=0 \cdot 045)$, a significant difference among FN concentrations $(F-$ ratio $=10 \cdot 78$, $P=0.009)$, and a significant interaction $(F-$ ratio $=17 \cdot 7$, $P<0 \cdot 001)$. Moreover, two-way ANOVA for comparison of RGE to RGDSP indicated a significant difference between CTRL + RGE and CTRL+RGDSP $(F$-ratio $=10 \cdot 73$, $P=0 \cdot 010)$, a significant difference among FN concentrations $(F$-ratio $=4 \cdot 88, P=0.049)$, and a significant interaction $(F-$ ratio $=17 \cdot 7, P<0 \cdot 001)$. This data are consistent with the reduction of $\alpha_{v} \beta 3$ expression and/or reduced affinity of $\alpha 3 \beta 1$ to $F N$ induced by IFN $-\gamma$.

\section{Effect of IFN- $\gamma$ on the cell cycle and survival}

The effect of IFN- $\gamma$ on the cell cycle was evaluated in TAD2 by flow cytometry analysis. TAD 2 cells were plated onto FN-coated plates and cultured for 3 days in the presence of IFN- $\gamma$ or left untreated. Then, all the cells, both floating in the medium and adherent, were collected, stained with propidium iodide, and analyzed by FACScan (Fig. 3A). The number of cells in the G0-G1 phase decreased from $49 \%$ in untreated cells to 38 and $34 \%$ after 10 and $100 \mathrm{ng} / \mathrm{ml} \mathrm{IFN- \gamma}$ treatment respectively. The number of hypodiploid cells

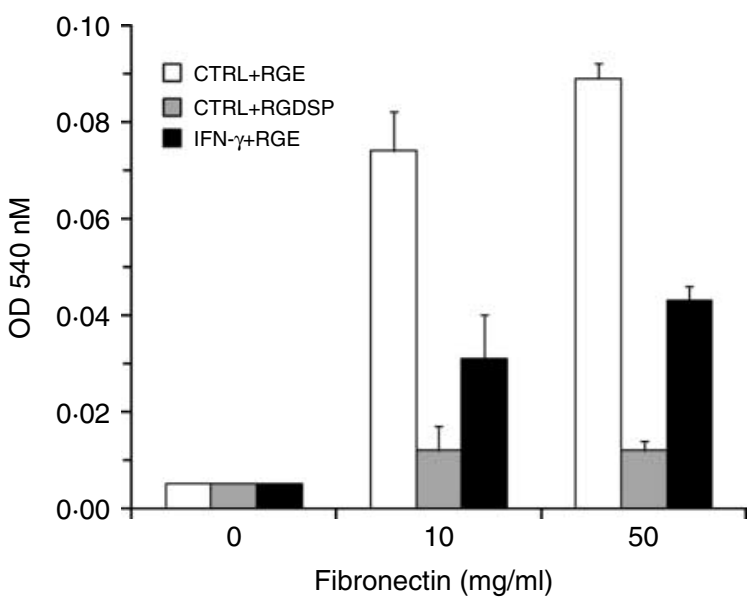

Figure 2 Effect of IFN- $\gamma$ on thyroid cell adhesion to FN. Ninety-sixwell microtiter plates were coated with soluble FN at 10 or $50 \mu \mathrm{g} / \mathrm{ml}$ and saturated with heat denatured BSA. TAD2 cells were untreated (CTRL) or treated with IFN- $\gamma, 10 \mathrm{ng} / \mathrm{ml}$ for 3 days. A total of $2 \times 10^{4}$ thyroid cells were seeded in the wells, with RGE or RGDSP peptides, and the plates were incubated at $37^{\circ} \mathrm{C}$ for $30 \mathrm{~min}$. Attached cells were measured as described in Materials and Methods section. Data are reported as the mean \pm s.D. of quadruplicate experiments. RGE and RGDSP, $500 \mu \mathrm{g} / \mathrm{ml}$. Two-way ANOVA analysis for IFN- $\gamma$ : IFN- $\gamma+$ RGE vs CTRL + RGE $(F$-ratio $=5 \cdot 38, P=0 \cdot 045)$, among $\mathrm{FN}$ concentrations $(F$-ratio $=10 \cdot 78, P=0 \cdot 009)$, interaction ( $F$-ratio $=17 \cdot 7, P<0 \cdot 001)$. Two-way ANOVA for comparison of RGE to RGDSP: CTRL + RGE vs CTRL+RGDSP $(F$-ratio $=10 \cdot 73$, $P=0 \cdot 010)$, among FN concentrations $(F$-ratio $=4 \cdot 88, P=0 \cdot 049)$, interaction $(F$-ratio $=17 \cdot 7, P<0 \cdot 001)$. 
A

IFN- $\gamma(\mathrm{ng} / \mathrm{ml})$

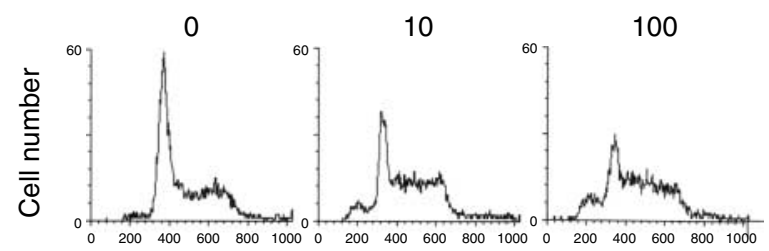

Relative fluorescence

\begin{tabular}{cllc}
$\begin{array}{c}\mathrm{IFN}-\gamma \\
(\mathrm{ng} / \mathrm{ml})\end{array}$ & A0 & G0-G1 & $\begin{array}{c}\mathrm{S}+ \\
\mathrm{G} 2-\mathrm{M}\end{array}$ \\
\hline 0 & $2 \cdot 9$ & $49 \cdot 5$ & 47.6 \\
10 & $10 \cdot 6^{\star *}$ & $37 \cdot 8^{* *}$ & $51 \cdot 6$ \\
100 & $14 \cdot 0^{\star *}$ & $33 \cdot 9^{\star *}$ & $52 \cdot 1$
\end{tabular}

B
0

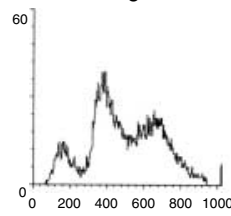

11.9
IFN- $\gamma(\mathrm{ng} / \mathrm{ml})$

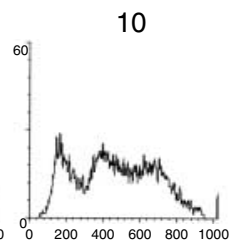

$23 \cdot 3^{*}$

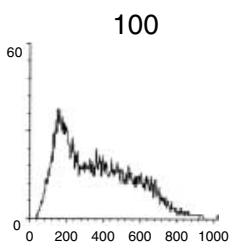

$39 \cdot 5^{\star *}$
Figure 3 DNA cell content of IFN- $\gamma$ treated cells. (A) TAD2 cells were plated onto $10 \mu \mathrm{g} / \mathrm{ml} \mathrm{FN-coated} \mathrm{plates} \mathrm{and} \mathrm{cultured} \mathrm{for} 3$ days in the presence of 10 or $100 \mathrm{ng} / \mathrm{ml} \mathrm{IFN}-\gamma$ or left untreated. Then, both adherent and suspended cells were collected, stained with propidium iodide, and analyzed by FACScan. (B) The cells were treated as in (A) for 6 days. S.D.s were $<15 \%$. A0, hypodiploid cells. Experimental point vs 0 point: ${ }^{*} P<0 \cdot 05,{ }^{* *} P<0 \cdot 005$ by Student's $t$-test.

increased from $2 \cdot 9$ to $11 \%$ and $14 \%$. The presence of a large number of DNA-loosing cells prevented distinguishment between $\mathrm{S}$ and $\mathrm{G} 2-\mathrm{M}$ phases, which appeared merged. By 6 days of treatment, the effect of IFN- $\gamma$ was massive, about $20 \%$ of the cells were detached and up to $39 \cdot 5 \%$ of the cells (both floating and adherent) were hypodiploid (Fig. 3B). These data demonstrate a time- and concentration-dependent cytotoxicity of IFN- $\gamma$.

IFN- $\gamma$ induces apoptosis in thyroid cells

Caspase-3 cleavage and PARP fragmentation were investigated by western blot to assess the occurrence of apoptosis (Fig. 4). TAD2 cells were treated for 3 days with IFN- $\gamma$ and analyzed, demonstrating that the hypodiploid cells were due to loss of fragmented DNA following apoptosis.

\section{Effect of IFN- $\gamma$ on FN-induced signaling}

To determine whether IFN- $\gamma$ affects the Ras/Raf/MEK/ ERK and phosphatidyl-inositol 3 kinase (PI3K)/AKT signaling, thyroid cells were untreated or treated with IFN- $\gamma$ for 3 days, starved from serum overnight, and plated onto immobilized BSA or FN. ERK phosphorylation was achieved by serum stimulation. After $30 \mathrm{~min}$, the cells were lysed and phosphorylated Akt or ERK were evidenced by western blot (Fig. 5). Adhesion to FN stimulated both Akt and ERK phosphorylation. The treatment with IFN- $\gamma$ strongly inhibited FN-induced phosphorylation of both kinases.

\section{Discussion}

IFN- $\gamma$, TNF- $\alpha$, and IL2 can modulate the expression of $\beta 1$ integrins, and therefore change the cell-ECM interaction in some cell types including fibroblasts, endothelial cells, and lymphoid cells (Pirila \& Heino 1996). It has been proposed that adhesion molecules are involved in the maintenance of autoimmunity. Some cytokines induce upregulation of $\alpha 1 \beta 1$, enhancing the persistence of inflammatory cells in the extralymphatic tissues and the in-site production of cytokines (Ben-Horin \& Bank 2004). However, the effects of inflammatory cytokines on thyroid integrin expression and function remained poorly investigated (Marazuela et al. 1997). Our study demonstrates that IFN- $\gamma$ has a cytotoxic effect and modulates integrin expression and function in the TAD2 cell line. This cell line was demonstrated to be a reliable model to study cell-ECM interactions as it has the same integrin expression profile and FN-stimulated signaling of normal human thyroid cells in culture (Vitale et al. 1997, 1998, Illario et al. 2003). Indeed, some of the experiments of this study have been performed with identical results in thyroid primary cultures (Russo et al. 2012). All the experiments were performed with TAD2 cells cultured at 75\% confluence to normalize integrin expression, which is downregulated by cell-to-cell contact (Vitale et al. 1995). Thyroid cells are polarized epithelial cells, whose basal plasma membrane adheres to ECM components of the basal membrane.

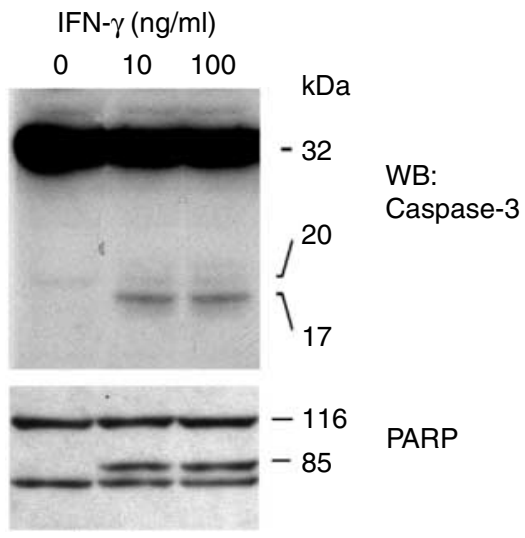

Figure 4 Western blot analysis of caspase- 3 and PARP in IFN- $\gamma$ treated cells. TAD2 cells were plated onto $10 \mu \mathrm{g} / \mathrm{ml} \mathrm{FN-coated}$ plates and cultured for 3 days in the presence of 10 or $100 \mathrm{ng} / \mathrm{ml} \mathrm{IFN}-\gamma$ or left untreated. Cell lysates were analyzed by western blot with antibodies to caspase-3 and PARP. 

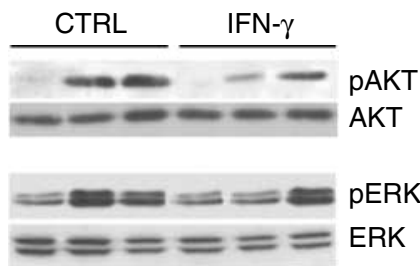

\begin{tabular}{|c|c|c|c|c|c|c|}
\hline BSA & + & - & - & + & - & - \\
\hline $\mathrm{FN}$ & - & + & 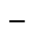 & - & + & - \\
\hline FCS & - & - & + & - & - & + \\
\hline
\end{tabular}

Figure 5 Stimulation of AKT and ERK phosphorylation by adhesion to FN. TAD2 cells were untreated or treated with IFN- $\gamma 10 \mathrm{ng} / \mathrm{ml}$ for 3 days. The cells were starved from serum overnight, harvested by mild trypsinization, and seeded in serum-free medium onto BSA-coated plates (BSA) or $50 \mu \mathrm{g} / \mathrm{ml} \mathrm{FN-coated} \mathrm{plates} \mathrm{(FN),} \mathrm{or}$ untreated plates in the presence of $10 \%$ FCS for $30 \mathrm{~min}$. The cells were lysed and the proteins were analyzed by western blot with antibodies anti-total (AKT and ERK) or anti-phosphorylated AKT ERK (pAKT and pERK).

Impaired adhesion to FN modifies outside-in signaling, inhibits cell proliferation, and triggers a programed cell death known as 'anoikis' (Vitale et al. 1997, 1998, 1999, Di Matola et al. 2000, Illario et al. 2003, 2005). The adhesion assays, with the highly specific integrin/FN-binding inhibitor RGDSP, demonstrated that thyroid cell adhesion to $\mathrm{FN}$ was almost exclusively mediated by $\beta 1$ integrins. Therefore, $\alpha 3 \beta 1$ and $\alpha v \beta 3$, the only $\beta 1$ integrins expressed, are the adhesion molecules involved in thyroid cell adhesion to FN. While $\alpha 3 \beta 1$ is localized on the entire plasma membrane facing the basal membrane and has mainly a structural function, $\alpha \mathrm{v} \beta 3$ is localized in the focal adhesions and mediates FN outside-in signaling. Inhibition of $F N / \alpha_{v} \beta 3$ binding and the succeeding signaling have important consequence for the cell, including inhibition of proliferation and induction of apoptosis. IFN- $\gamma$ induced a modest upregulation of $\alpha 3 \beta 1$ expression and a more evident downregulation of $\alpha_{\mathrm{v}} \beta 3$ in TAD2 cells. The remarkably impaired adhesion to $\mathrm{FN}$ might be due to the more relevant reduction of $\alpha_{\mathrm{v}} \beta 3 / \mathrm{FN}$ interaction. However it cannot be excluded that IFN- $\gamma$ possibly reduced the binding affinity of one or both the receptors. Indeed, the affinity of integrin receptors for their ligands is cell-type-dependent and modulated by different factors (Wilkins et al. 1991). The cytotoxic effect of IFN- $\gamma$ was an apoptotic process, as demonstrated by the caspase- 3 and PARP cleavage. This cytokine generates a pleiotropic signaling with multiple effects. It has been previously demonstrated that impairment of $\alpha v \beta 3$ adhesion to $\mathrm{FN}$ induces apoptosis in thyroid cells (Vitale et al. 1998, Illario et al. 2003). Although a direct involvement of this integrin in the cytotoxic effect of IFN- $\gamma$ was not demonstrated in our study, it can be speculated that the inhibition of MAPK and PI3K/AKT signaling is involved in the apoptotic process induced by this cytokine. Indeed, the inhibition of the AKT survival pathway, the same of many growth factors necessary for cell survival, makes the thyroid cell more sensitive to damaging agents and thus might contribute to the cytotoxicity of IFN $-\gamma$ or of other damaging mechanisms active in the HT. In conclusion, our study in a thyroid cell model demonstrates that IFN- $\gamma$ induces apoptosis and inhibits the expression of the integrin $\alpha_{v} \beta 3$, reducing cell adhesion to FN and the succeeding outside-in signaling. These results suggest that integrins mediate the cytotoxic effect of IFN- $\gamma$ and play a role in the destructive mechanism of autoimmune thyroiditis.

\section{Declaration of interest}

The authors declare that there is no conflict of interest that could be perceived as prejudicing the impartiality of the research reported.

\section{Funding}

This work has been supported in part by Ministero dell'Istruzione, dell'Università e della Ricerca (to $\mathrm{M} \mathrm{V}$ ).

\section{References}

Ben-Horin S \& Bank I 2004 The role of very late antigen-1 in immunemediated inflammation. Clinical Immunology 113 119-129. (doi:10.1016/ j.clim.2004.06.007)

Carter LL \& Dutton RW 1996 Type 1 and type 2: a fundamental dichotomy for all T-cell subsets. Current Opinion in Immunology 8 336-342. (doi:10.1016/S0952-7915(96)80122-1)

Caturegli P, Kimura H, Rocchi R \& Rose NR 2007 Autoimmune thyroid diseases. Current Opinion in Rheumatology 19 44-48. (doi:10.1097/ BOR.0b013e3280113d1a)

Dedhar S 1989 Regulation of expression of the cell adhesion receptors, integrins, by recombinant human interleukin- $1 \beta$ in human osteosarcoma cells: inhibition of cell proliferation and stimulation of alkaline phosphatase activity. Journal of Cellular Physiology 138 291-299. (doi:10.1002/ jcp.1041380210)

Di Matola T, Mueller F, Fenzi G, Rossi G, Bifulco M, Marzano LA \& Vitale M 2000 Serum withdrawal-induced apoptosis in thyroid cells is caused by loss of fibronectin-integrin interaction. Journal of Clinical Endocrinology and Metabolism 85 1188-1193. (doi:10.1210/jc.85.3.1188)

Heino J \& Massague J 1989 Transforming growth factor- $\beta$ switches the pattern of integrins expressed in MG-63 human osteosarcoma cells and causes a selective loss of cell adhesion to laminin. Journal of Biological Chemistry $26421806-21811$.

Hemler ME, Huang C \& Schwarz L 1987 The VLA protein family. Characterization of five distinct cell surface heterodimers each with a common 130,000 molecular weight beta subunit. Journal of Biological Chemistry 262 3300-3309.

Illario M, Amideo V, Casamassima A, Andreucci M, di Matola T, Miele C, Rossi G, Fenzi G \& Vitale M 2003 Integrin-dependent cell growth and survival are mediated by different signals in thyroid cells. Journal of Clinical Endocrinology and Metabolism 88 260-269. (doi:10.1210/jc. 2002-020774)

Illario M, Cavallo AL, Monaco S, Di Vito E, Mueller F, Marzano LA, Troncone G, Fenzi G, Rossi G \& Vitale M 2005 Fibronectin-induced proliferation in thyroid cells is mediated by $\alpha_{\mathrm{v}} \beta 3$ integrin through Ras/Raf-1/MEK/ERK and calcium/CaMKII signals. Journal of Clinical Endocrinology and Metabolism 90 2865-2873. (doi:10.1210/jc.2004-1520)

Liblau RS, Singer SM \& McDevitt HO 1995 Th1 and Th2 CD4 + T cells in the pathogenesis of organ-specific autoimmune diseases. Immunology Today 16 34-38. (doi:10.1016/0167-5699(95)80068-9)

Luna EJ \& Hitt AL 1992 Cytoskeleton - plasma membrane interactions. Science 258 955-964. (doi:10.1126/science.1439807) 
Marazuela M, De Landazuri MO, Larranaga E \& Sanchez-Madrid F 1997 Up-regulated $\beta 1$-integrin expression in autoimmune thyroid disorders. Clinical and Experimental Immunology 109 107-115. (doi:10.1046/j.13652249.1997.4171323.x)

Mazziotti G, Sorvillo F, Naclerio C, Farzati A, Cioffi M, Perna R, Valentini G, Farzati B, Amato G \& Carella C 2003 Type-1 response in peripheral $\mathrm{CD} 4+$ and $\mathrm{CD} 8+\mathrm{T}$ cells from patients with Hashimoto's thyroiditis. European Journal of Endocrinology 148 383-388. (doi:10.1530/eje.0.1480383)

Mortarini R, Gismondi A, Santoni A, Parmiani G \& Anichini A 1992 Role of the $\alpha 5 \beta 1$ integrin receptor in the proliferative response of quiescent human melanoma cells to fibronectin. Cancer Research 52 4499-4506.

Otey CA, Pavalko FM \& Burridge K 1990 An interaction between $\boldsymbol{\alpha}$-actinin and the $\beta 1$ integrin subunit in vitro. Journal of Cell Biology 111 721-729. (doi:10.1083/jcb.111.2.721)

Pala P, Hussell T \& Openshaw PJ 2000 Flow cytometric measurement of intracellular cytokines. Journal of Immunological Methods 243 107-124. (doi:10.1016/S0022-1759(00)00230-1)

Pasqualini R \& Hemler ME 1994 Contrasting roles for integrin $\beta 1$ and $\beta 5$ cytoplasmic domains in subcellular localization, cell proliferation, and cell migration. Journal of Cell Biology 125 447-460. (doi:10.1083/ jcb.125.2.447)

Pirila L \& Heino J 1996 Altered integrin expression in rheumatoid synovial lining type B cells: in vitro cytokine regulation of $\alpha 1 \beta 1, \alpha 6 \beta 1$, and $\alpha \mathrm{v} \beta 5$ integrins. Journal of Rheumatology 23 1691-1698.

Plantefaber LC \& Hynes RO 1989 Changes in integrin receptors on oncogenically transformed cells. Cell 56 281-290. (doi:10.1016/00928674(89)90902-1)

Romagnani S 1994 Lymphokine production by human T cells in disease states. Annual Review of Immunology 12 227-257. (doi:10.1146/annurev. iy.12.040194.001303)

Roura-Mir C, Catalfamo M, Sospedra M, Alcalde L, Pujol-Borrell R \& Jaraquemada D 1997 Single-cell analysis of intrathyroidal lymphocytes shows differential cytokine expression in Hashimoto's and Graves' disease. European Journal of Immunology 27 3290-3302. (doi:10.1002/eji. 1830271228)

Roura-Mir C, Catalfamo M, Cheng TY, Marqusee E, Besra GS, Jaraquemada D \& Moody DB 2005 CD1a and CD1c activate intrathyroidal T cells during Graves' disease and Hashimoto's thyroiditis. Journal of Immunology 174 3773-3780.

Russo E, Salzano M, Postiglione L, Guerra A, Marota V \& Vitale M 2012 Interferon- $\gamma$ inhibits integrin-mediated ERK activation stimulated by fibronectin binding in thyroid cells. Journal of Endocrinological Investigation. In press. (doi:10.2375/8649)

Salgame P, Abrams JS, Clayberger C, Goldstein H, Convit J, Modlin RL \& Bloom BR 1991 Differing lymphokine profiles of functional subsets of human CD4 and CD8 T cell clones. Science 254 279-282. (doi:10.1126/ science.1681588)

Santaguida MG, Nardo S, Del Duca SC, Lococo E, Virili C, Gargano L, Lenti L \& Centanni M 2011 Increased interleukin-4-positive lymphocytes in patients with Hashimoto's thyroiditis and concurrent non-endocrine autoimmune disorders. Clinical and Experimental Immunology 165 148-154. (doi:10.1111/ j.1365-2249.2011.04419.x)
Stassi G, Di Liberto D, Todaro M, Zeuner A, Ricci-Vitiani L, Stoppacciaro A, Ruco L, Farina F, Zummo G \& De Maria R 2000 Control of target cell survival in thyroid autoimmunity by $\mathrm{T}$ helper cytokines via regulation of apoptotic proteins. Nature Immunology 1 483-488. (doi:10.1038/82725)

Stassi G, Zeuner A, Di Liberto D, Todaro M, Ricci-Vitiani L \& De Maria R 2001 Fas-FasL in Hashimoto's thyroiditis. Journal of Clinical Immunology 21 19-23. (doi:10.1023/A:1006732713634)

Tunbridge WM, Evered DC, Hall R, Appleton D, Brewis M, Clark F, Evans JG, Young E, Bird T \& Smith PA 1977 The spectrum of thyroid disease in a community: the Whickham survey. Clinical Endocrinology $\mathbf{7}$ 481-493. (doi:10.1111/j.1365-2265.1977.tb01340.x)

Tunbridge WM, Brewis M, French JM, Appleton D, Bird T, Clark F, Evered DC, Evans JG, Hall R, Smith P et al. 1981 Natural history of autoimmune thyroiditis. BMJ 282 258-262. (doi:10.1136/bmj.282.6260.258)

Vitale M, Bassi V, Fenzi G, Macchia PE, Salzano S \& Rossi G 1993 Integrin expression in thyroid cells from normal glands and nodular goiters. Journal of Clinical Endocrinology and Metabolism 76 1575-1579. (doi:10.1210/jc. 76.6.1575)

Vitale M, Bassi V, Illario M, Fenzi G, Casamassima A \& Rossi G 1994 Loss of polarity and de novo expression of the $\beta 1$ family of integrins in thyroid tumors. International Journal of Cancer 59 185-190. (doi:10.1002/ijc. 2910590208)

Vitale M, Casamassima A, Illario M, Bassi V, Fenzi G \& Rossi G 1995 Cell-to-cell contact modulates the expression of the $\beta 1$ family of integrins in primary cultures of thyroid cells. Experimental Cell Research 220 124-129. (doi:10.1006/excr.1995.1298)

Vitale M, Illario M, Di Matola T, Casamassima A, Fenzi G \& Rossi G 1997 Integrin binding to immobilized collagen and fibronectin stimulates the proliferation of human thyroid cells in culture. Endocrinology $\mathbf{1 3 8}$ 1642-1648. (doi:10.1210/en.138.4.1642)

Vitale M, Di Matola T, Fenzi G, Illario M \& Rossi G 1998 Fibronectin is required to prevent thyroid cell apoptosis through an integrin-mediated adhesion mechanism. Journal of Clinical Endocrinology and Metabolism 83 3673-3680. (doi:10.1210/jc.83.10.3673)

Vitale M, Di Matola T, Bifulco M, Casamassima A, Fenzi G \& Rossi G 1999 Apoptosis induced by denied adhesion to extracellular matrix (anoikis) in thyroid epithelial cells is p53 dependent but fails to correlate with modulation of p53 expression. FEBS Letters 462 57-60. (doi:10.1016/ S0014-5793(99)01512-4)

Wilkins JA, Stupack D, Stewart S \& Caixia S 1991 B1 Integrin-mediated lymphocyte adherence to extracellular matrix is enhanced by phorbol ester treatment. European Journal of Immunology 21 517-522. (doi:10.1002/ eji.1830210239)

\section{Received in final form 28 September 2012 \\ Accepted 1 October 2012}

Made available online as an Accepted Preprint

1 October 2012 